\title{
Finding God in All Things: Identity and Purpose in a Jesuit Community for the Elderly
}

\author{
Jon-Michael Odean
}

\begin{abstract}
This article is an investigation into the development and maintenance of identity of elderly Jesuits residing in the Jesuit Community for the Elderly (JCE) in Maryland. Through qualitative research and analysis using identity theory, I investigate the human creature as an embodied being oriented to perceive and respond to meaning, and to construct identity out of the process. I look to see the means by which these individuals, especially in the context of a religious order and old age, create and maintain their identities. I conclude that with the intentional practice and construction of foundational habits in the context of community, the residents of the JCE, no matter their state of physical deterioration at this late stage in the life cycle, are able to maintain their identity as Jesuits, continue relational practice through ministry, and maintain a profound sense of meaning in life.
\end{abstract}

At the end of a conversation lasting the better part of an hour, I was getting up to end my time with Father Hillary when he looked at me and asked, "So have you written down everything that you need?" As one who has heard stories of researchers finding their best information after they had packed up and finished their formal interviews, I was ready. Pausing immediately, still determined to take every last drop of information he was willing to concede, I answered, "I think I have gone through everything I can think of, but what's up?" He then sat back down and said, "Let me tell you a story that captures what it means to be a Jesuit." I sat back down and looked at the man in front of me, seeing in his eyes he was suddenly transported to a time long since passed.

"Many years ago, when I was in seminary in Maryland, there was a group of us Jesuits that would frequently go out after class to a large field near the school to relax and socialize. Close to this field in the same area of Maryland was a fairly large prison. Now, there was a Jesuit priest who worked as the prison chaplain by the name of Father Abraham Bauer. This is a story of Father Bauer's that had a profound impact on me, and illustrates what it means to be a Jesuit.

Jon-Michael Odean, M.A. is an adjunct professor of anthropology at Eastern University. Author email: jmodean@gmail.com.
"Now Father Bauer was not raised Catholic. Early on in his life he was raised in a strict Jewish Orthodox family. When he was around twelve years old he had a powerful conversion experience, but since his family was strictly Jewish, he told no one about this happening. Every Sunday, he would attend Mass but would tell his family he was going for a walk or running some other errand for hours at a time. Eventually he was discovered, which caused quite a bit of strife and tension within his family. It was during this time that his resolve to be a part of the Church was strengthened, and he knew he wanted to take religious orders. So, as the years went by, he eventually became a Jesuit priest whose ministry was centered on the prisoners of this jail near his home in Maryland as the prison chaplain.

"While I was in seminary, Father Bauer would meet with and tend to the needs of those prisoners on death row as part of his ministry. Every day he would meet with them, talk with them, and pray with them. Often he was simply present, the only visitor to those the world had forgotten. Over time he got to know the prisoners very well and developed very deep relationships with some of these people. Around this time he met one prisoner named David who was very young. Now legally he wasn't a boy but in reality he really was just a kid and most certainly should not have been there. I mean, this guy really had his whole life in front of him and, due to an unfortunate tragedy, his life was forfeit. Sadly, this young man was sentenced to death. While he was on death row, Father Bauer started meeting with and ministering to David. During this 
period Father Bauer had grown very close to this young man, who, besides the priest, had no one. Outside of his time with Father Bauer and interactions with the prison staff, David was left utterly alone devoid of any human interaction, let alone the decency of any friendship, or afforded even the slightest trace of compassion.

"Every day, especially as time got closer to the day of his execution, Father Bauer visited to spend time with David. Most days they would pray, read scripture, or simply be present and converse with each other. With his impending death, David was often terrified. He would regularly express these fears to Father Bauer, uttering 'I am so alone,' or simply whispering, 'I am going to die Father, and I am so scared.' On the eve of his execution, when Father Bauer gave him the last rites, David looked up to him and said, 'I am so afraid, and I really have no one.' Father Bauer looked into his eyes and said, 'You have me. You just look right at me and I will be with you the whole time.'

"On the next day at the time of the scheduled execution, David was led into the chamber and prepared to die. On the far wall of the chamber was placed a massive glass window providing a view for those there to witness the deed. Most were there to coldly witness retribution, to observe the act and collect payment in full to gain their perceived justice. However, within the cold sea of hate and sorrow was an outlierfor among those in attendance was Father Bauer. And Father Bauer sought no easy exchange on this day, for he knew the great cost he must pay. With great strength he stood upright, his face pressed against the glass as he watched his friend, someone whom he loved, being made ready to die. As the execution started, the young prisoner immediately searched for the eyes of Father Bauer. In that same moment, Father Bauer latched directly onto his young friend's eyes, restoring the dignity to young David, gifting him with what others in attendance so hopefully attempted to deny. Returning fear with kindness and combating the overwhelming hate with love, Father Bauer sought to be fully present with David in this moment. As the execution began, without flinching or looking away, Father Bauer held his gaze, locked onto the eyes of his dear friend, full of terror, as his life slowly slipped away. And when the deed was done, and the life was forfeit, Father Bauer was filled with such rage and hatred that he immediately left the prison.

"After exiting the prison, he saw a group of girls playing and laughing outside-completely unaware of what had just happened only a short distance away. Witnessing the joy and hearing the laughter of these girls, he felt his heart swell full of rage and hate and thought, 'no one-no one-has any right to be happy or joyful right now.' Upon feeling and thinking these thoughts, Father Bauer realized that there was something wrong in his heart at that moment. Instead of dwelling on these feelings, he immediately took off running in the field. He ran with urgency and vigor, as if he was protesting evil's grip or death itself with his entire body. After running a distance, he came upon a group of other Jesuits lying out in the field, myself included, and stopped. He looked at us with a look of desperation, sadness, and anger on his face. He said, 'I need to share something with you,' and proceeded to break down as he told us the story of what had just happened. And in that moment as a community we were with him. We listened, we cried, we prayed and we loved. And on the Monday of the next week, he went right back to the jail, started the cycle all over again, with new prisoners, new friends, and new heartbreaks." As he finished, Father Hillary turned to look at me directly in the eyes and said, "And that is what it means to be a Jesuit."

\section{Human Identity}

Few areas of study have explored the depths of the uniquely human phenomenon of identity, identityformation, and maintenance as the discipline of anthropology. Through an inherently relational process, humans develop an identity that guides their ability to construct and engage their perceived reality. As human beings, we are deeply meaning-laden creatures. Within a socially-organized community, through symbolic communication means, we humans ultimately come to a knowledge of our 'selves' as placed within a socially constructed system of meaning.

George Herbert Mead and his successors were early researchers into this question and ultimately produced the school of thought in symbolic interactionism (Mead et al. 1934; 1936). The development of the self, they argued, was accomplished through reflexive intelligence, the human brain's ability to take on the persona of the group juxtaposed to the individual through engaging in an internal conversation. Following Mead, Herbert Blumer built symbolic interactionism's theoretical framework to explain how humans create social structures using symbolic means (Blumer 1969). Humans create symbols to represent and organize aspects of the social world. Meaning emerges from this process, in no small part because of the requirement for a response on the part of the individual. Peter Burke (Burke and Stets 2009), George McCall (1970), and J.L. Simmons (McCall and Simmons 1978) have contributed further to the interactionist approach by studying and theorizing the development of identity in the roles established by social mapping, thereby expanding what we know today as identity theory.

We can define identity as, "the set of meanings that define who one is when one is an occupant of a 
particular role in society, a member of a particular group, or claims particular characteristics that identify him or her as a unique person" (Burke and Stets 2009:3). We must note the importance of the self here. Because an individual normally carries multiple roles, these roles need to be organized into a hierarchy residing within the conceptualized self (39). This is what McCall and Simmons have deemed the prominence hierarchy of identities (1978). In general the hierarchy is organized by how the individual likes to see or conceptualize him or herself based on ideals, desires, or perceived central importance emerging from socially constructed meaning (Burke and Stets 2009:39).

The placement of these individual identities within the hierarchical system is influenced by three major factors-support, commitment, and rewards. ${ }^{2}$ McCall asserts that these factors "influence the prominence hierarchy, or what...[we] sometimes label the ideal self" (1970:40). Higher placement on the hierarchy results in greater self-esteem, affirming good feelings or positive emotions when the individual believes they are fulfilling the total embodiment of that claimed identity.

Here we can see an intersection of social theory and theological assumptions by observing the inherent communal construction of both the human person and the Trinity. As Mead and his interactionist successors suggest, the human person emerges through dynamic interactive relationships with others from its placement within the social web of its community. The Trinity in Christian thought is a communally self-constructing entity in that three distinct Persons can only be who they are through their relations with each other and are united in an asymmetrical manner, with each being uniquely divine. While each of the individual Persons has that divine nature in common, they also have a particular individual nature that is determined by their relationship to one another. Thus, there is dialogue between the individual Persons and the divine whole, out of which the Godhead of the Trinity emerges.

In what follows, I will describe and analyze the formation of identity among the members of the Society of Jesus as I encountered them in a late-life assisted living residence, the Jesuit Community for the Elderly (JCE), ${ }^{3}$ in Maryland. Using identity theory, I investigate the human creature as an embodied being oriented to perceive and respond to meaning, and to construct identity out of the process. The ultimate purpose of this work is to describe the means by which individuals, especially in the context of a religious order and old age, create and maintain their identities.

\section{The Jesuit Community for the Elderly}

The Jesuit order is a unique community of individuals bound together by five major commitments, three vows and two principles: a vow of chastity, a vow of poverty, a vow of obedience, ${ }^{t}$ the virtue of indifference, and finding God in all things. Each of these commitments will be explained below.

The order was founded by St. Ignatius of Loyola, a $16^{\text {th }}$ century Spanish priest who had had a very deep and profound conversion experience. Both critics and followers of Ignatius' view him as an extreme individual. In the life of Ignatius, one sees a radical transformation from a soldier of noble birth to a life of service in the Church. ${ }^{5}$ The Jesuit Order, also known as The Society of Jesus, has a long and dynamic history, and now boasts 16,000 members worldwide. It is broken up into regional governing provinces, with approximately 290 members in Maryland's province alone. The residents of JCE have a primary identity as Jesuits, but are experiencing this identity in the context of old age.

\footnotetext{
1 There are five central ideas that are crucial to this theory's foundation. First, symbols and meaning shape our perceptions of the world and objects/categories within it. Second, the individual is able to look at the self as an entity full of meaning both from the individual and the group's perspective. Third, is "the gesture as containing meaning representing the intentions of the complete act of an actor that allows an understanding of intentions and goals of others and the self." Fourth, there is a relationship between the individual and the situation by a "dynamic control system containing an active agent part and a passive perceptive part" that necessitates a constant adjustment allowing both the individual to fit its environment and the environment to be shaped by the individual. Finally, "the fit of the individual in its environment and with others in the situation has consequences for self-feelings and emotions of the individual, which feelings and emotions instigate and guide further action” (Burke and Stets 2009:32).
}

\footnotetext{
${ }^{2}$ Support: The degree to which an individual is able to experience received support from others in the community or create selfsupport for a particular identity. Commitment: The amount that in individual is invested in any particular role. Rewards: Positive compensation received by the individual for the fulfillment of a particular identity, both intrinsically and extrinsically.
}

${ }^{3}$ This is a pseudonym for the community. All personal names have been changed along with some identifying places and markers.

"The vow of obedience has a specific bent towards being sent and living life as mission. Since Ignatius spent his days in Rome in constant communication with the Pope, this third vow soon came to have a qualified additional interpretation: not only being sent by one's superior, but also obedience to the Pope to carry out the overall mission of the Church. This led to the colloquial addendum of obedience being the third vow, and obedience to the Pope, a fourth.

${ }^{5}$ This article does not address Jesuit spirituality itself, which cannot be captured by systemic analysis or a set of rules and practices. Ignatian spirituality resides more in the ontological construction of the individual, and a spiritual way of proceeding. For a robust account of this spirituality see: David Fleming (2008). 
Historically, Jesuits in Maryland have resided within their ministry areas and been cared for by those around that ministry when becoming elderly. There has been no community designed specifically for the elderly. But, with members living longer due to medical advancements, the JCE officially opened its doors in 2011-an intentionally designed community solely for those Jesuits needing low-level assisted care. Maintaining state-of-the-art medical facilities, the residence has the capacity to house 41 residents on a beautiful campus of 14 acres.

The benefit of studying something as vast as what it means to be a Jesuit in this community is that all residents of the community have lived a long life of contemplation. At this stage in the lifecycle, identity is a subject that most of the residents have thought about plenty. Though the age range of my informants spans over 40 years, when asked what it means to be a Jesuit, I found much the same answer with only slight nuances. JCE's Superior, Father Grant, gave a direct answer upon my first visit. Though he is the youngest resident, he has a degree in gerontology and is prepared for the duty of running this community. He, like most Jesuits I have come to know, has lived life in such a way as to prepare him to be particularly qualified for his occupation, and to allow the level of excellence shown in his work to be a witness and ministry itself. According to Father Grant, then, to be a Jesuit in its most literal and possibly weighty sense is to be a part of a community founded by St. Ignatius of Loyola. It is a life of ministry. The ultimate intention of that ministry is to lead souls to God. But this aspiration requires the full submission of one's own life to the will of God in the mission to which they are called.

Over the course of one's life as a Jesuit, there is an emphasis on extensive training and education to prepare one for a completely integrated life within ministry. Father Grant emphatically remarked, "Everything is the apostolate, everything you do is the motivation of, or lens, leading back to ministry. Everything we do is so we can be fully immersed in the apostolate, which ultimately points to God with the goal of leading those souls to God." While in the moment, I did not think this answer to be of any particular significance. However, in looking over my field notes later, and taking my entire research into account, I now realize that this is an important framing for the greater Jesuit community. Everything is truly done in an effort to fully immerse oneself in whichever ministry they are given, and every ministry has the foundation of being situated in the greater goal of the Jesuit Order as a whole: to lead souls to God.

Father Lawrence spent much of his life in ministry in North Carolina. In contrast with most of the residents, he has a shockingly youthful presence about him. He is someone who can instantly disarm a critic with a warm smile, a quick joke, and some goodnatured ribbing. To Father Lawrence, discovering what it means to be a Jesuit has been his life's journey. That journey has been to be a part of the Order; an Order started by St. Ignatius to build a community conformed to Christ. Now as a member of the JCE, life as a Jesuit is in a brand-new stage, and this presents him with new challenges due to having retired from direct ministry. What keeps him going is the spirituality of the Jesuits, "It has been a satisfying life; a long career that I would not have had any other way," states Father Lawrence.

"Before moving here I spent the majority of my career down in North Carolina which I loved and miss deeply. In fact transitioning into this house and community is possibly one of the hardest stages of my life." Staring at the man across from me, seemingly so full of life, I was somewhat taken aback by that statement. I asked him, 'What made this stage of his life so hard?' His response seemed to be parallel to many stories told by the elderly in our society. In fact, I felt as if I was sitting right across from my own grandfather who was recently forced into retirement after a long career as a medical doctor-another profession that seems to take over one's entire life. "In a life of ministry you always have something coming at you, and I think in this stage it is hard because I don't have those things coming at me and I have to be self-motivated to find them." I asked about Jesuit spirituality at this stage of life. In response the Father shifted, his gaze locking onto me as he answered, "I'm sure that [at] different times there was a sense of the presence of God in my life, that it was like He was in everything. At this time in my life, I know it's going to sound very strange, I can walk down a corridor that would drive me absolutely nuts because of the damn silence and I see God there. Because I know he's with me, and if he's with me, he's everywhere...Y You've got to love this crazy world. You have to see the goodness... It's very depressing to me at times, and if I let it get to me I would miss what I can be grateful for, and I don't have the right to, and I can hear God saying 'enjoy them'. It is hard living here, is hard living in this stage of life, but you have to create what will sustain you-that has got to be something meaningful and if you don't have something meaningful, find it."

Hearing this statement on the importance of finding something meaningful, I asked him what he does to find purpose in the monotony of daily life in the residence? Instantly, as if he were expecting this question, his face lit up and he jumped right in, eager to share his secret: "Now most of the men here love reading, but I've never been a reader so I've spent most of my waking time thinking 'art'. I didn't always have time to do it back when I was in ministry and I probably didn't always realize it was that important, but it is. If you love something, and have a passion for something, do it! Do 
it a little bit every day. I try to do something with art every day. It will sustain you and you'll find God in that."

I decided to push him a little more on art being a way of experiencing God and finding meaning. Originally, when he first mentioned painting as a passion that allowed him to find God in the residence, I had expected it to be a remnant of his life before ministry, a leftover from his pre-Jesuit days. Now, I thought, his art must have reemerged as a welcome respite, defying a utilitarianly-grey existence. I was foolishly categorizing the life of a Jesuit into partsbefore and after taking orders, before and after ministry. I asked the question, "How does anyone in this home, after fully dedicating their life to a distinct ministry now miles and years away, have the time to develop the skills needed to express these hidden passions?" As he stood leaning heavily for steadiness on his cane, reminiscent of a kickstand for a bicycle, Father Lawrence shifted slightly, orchestrating his response. After what seemed like a lifetime of silence, he looked down at the ground as if he were reading it as a prompt and started to answer, "I've been blessed because I've had some marvelous art lessons in painting which really is my true passion. Discovering the passion of painting saved me because it's what I do here during the day. I didn't realize how much of a passion I had until I took lessons with this Jewish guy down in North Carolina to get to know those around me. I only started about four years before I moved up here and I discovered I had a real passion for it. I've been here for five years, and I had lessons for four before that, so it's been about nine years now."

So, unbeknownst to him, it was during his ministry, his years of dedication to others, that Father Lawrence was being trained to adapt and flourish in this new community. For Father Lawrence, as with other residents I interviewed, the Jesuit life is a life based on giving up of one's own desires and dreams for the betterment of those around, but that in turn provides meaning and purpose to one's self, including in old age. To hammer that point home he continued, "Painting has really been my saving grace. Constantly, it reminds me of something that I think is a lesson you learn in all areas of life. Often it is not about the product that we produce, but the act and the process of creating that really matters and where we really are shaped. What good are you with an answer if you don't have to go looking for it?"

As seen in this instance, the Jesuit emphasis on living a fully integrated life has special bearing upon old age. I interviewed Father Damien, a licensed psychologist who practiced for over 20 years in the first stage of ministry before coming to be the chaplain at JCE. Compared to most current residents, he looked both physically and mentally out of place, and he immediately clarified that if he were not the chaplain he would not be residing in this home. Father Damien made the point that this is not a retirement homeJesuits do not retire from being a Jesuit nor from ministry, for that matter. They may retire from their occupation, but their lives continue to be ministerially centered. For, at the very essence of the order, being a Jesuit involves living a de-compartmentalized life, and to do that one must be fully immersed within a ministry of some kind at all times. At any point in time, all residents of this community are tasked with a specific ministry by the superior or the provincial of the order. Often the new ministry is praying for the order, a dramatic change from the previous more active ministry held by the members. As in all Jesuit ministries, you reside where your ministry takes place. For the member tasked with a prayer ministry in old age, it is at JCE.

\section{The Vows}

Crucial to understanding the Order, is to know that this is a community built upon three vows-chastity, poverty, and obedience. Investigating these vows with the Jesuits at JCE was a rare opportunity to see what they meant to those who kept them over the course of a lifetime of ministry. The vows are key to the framing of this community and are undergirded by two foundational principles: the virtue of indifference, and finding God in all things.

I was struck most by Father Donaghy's explanation of the importance of the vows to the Jesuit communityespecially at JCE. "Jesus' life can be described as very poor, he was chaste-he didn't get married, and he was obedient to the Father's will. And, of course, Jesuits have tacked on obedience to the Pope. So these vows are a summation of Jesus' life and the Jesuit life. Making these vows conforms our selves more fully to Jesus, as we want to be like him." The vows are also a concrete way in which the community of Jesuits can orient their life together. The vows come at a high cost, and one that sets them apart from the surrounding communities of their ministries. Yet, it is precisely through these vows that the Jesuits of this community believe they are mirroring their lives on that of Jesus'. Thus, to be a Jesuit is to live in submission to these vows with the intention of conforming oneself to Jesus Christ.

\section{Poverty}

Few vows more powerfully contradict the overriding symbol of success in our society than the vow of poverty. But, this is not the same poverty as practiced by the Franciscans-it achieves a different purpose. To anyone observing JCE, it is obvious that the complex facilities cost a great deal to build and maintain, and may conclude upon first impression that it does not 
exactly exude a spirit of poverty. Each day I was met by the superior, Father Grant, upon arrival at the residence. Over time I had developed enough of a rapport to ask a few tactfully blunt questions. I was struggling to find the evidence of this vow of poverty at JCE.

Father Grant reminded me, "Everything leads to the apostolate, including this vow. Everything is in light of your ministry. This is the vow that allows you to be at the level necessary to be fully immersed in your ministry, and allows you to minister to all those around you. It is the poverty of the apostolate." His comment helped me understand the Jesuit use of wealth better. It is important for those who run the home to provide for the Jesuits who have special needs, physical, emotional and spiritual. The aesthetic design and medical facilities achieve this purpose. But the purpose is not merely to provide comfort in old age; it is to assist the members to continue their ministerial work in whatever capacity they have as apostles of Jesus.

With the question still fresh in my mind, I went to ask it of Father Conrad, who had once been president of a university. Looking away, he answered, "Well obviously this poverty is not what you think of povertyI mean look at this house. But it means that you don't own anything of your own. I mean I have stuff, you know books and a computer, but really that all belongs to the society. So the poverty really means that you don't own anything." When pressed further he expounded, "A president's vow of poverty looks different than that of a normal Jesuit. I mean you go to have a lot of fancy dinners, be a part of different social clubs, and you travel a lot. So the thing is somehow to do all of that [for the needs of the job], but not get attached to it." I replied that that would be tough for me. Sheepishly he answered with an uncomfortable laugh, "Yes, yes it is. But you know when you've been raised this way las a Jesuit], after this long it's not so hard.”

Still not satisfied with my own understanding of how this vow operates in relatively comfortable occupations, I sought out Father Lawrence. Sensing my skepticism, leaning towards me with his cane as his prop he explained, "Basically I have still lived life in the middle class. For my personal self, it's not so much that I have had a lot of work with the immediate poor, but more of poverty as...a sense of letting go. You know that is absolutely important for me. To me there is a sense of poverty in that.”

Hearing this from someone whose life was dedicated to contemplative prayer and guiding people through intentional practice of spiritual development, I found myself finally seeing this vow in a new light. He continued, "Don't get me wrong, poverty is much more than that...you have to get permission to buy things, even something as simple as my clothes, its more about ownership. So you learn to be dependent upon the physical world in which you live, and that means you don't have everything that you want. I mean I know it sounds frustrating, especially in our society, but it's powerful. I drove a car for years but it wasn't mine-it was a gift-and then when it was decided I no longer had use for it, it was gone." Father Conrad's point is a potent one, but one that can only be completed by what I learned from Father Lawrence-this vow looks different when lived out by different Jesuits operating in different ministries, but the ethos is the same. Nothing is your own; everything belongs to the Order for the sake of the ministry of leading all souls to God. You will have everything that is needed for the sake of the ministry. It is this simplicity that makes poverty a powerful asset.

\section{Chastity}

Often to outsiders, the vow of chastity tends to be the most polarizing and misunderstood vow. Even now, communicating the fullness of its definition is more complicated than can actually be put into words. However, for the sake of a written account, and with the help of the community chaplain, I define it as: intentionally living a life of celibacy and refraining from an exclusive relationship with any other individual, whether female or male, in all forms of intimacy whether it be physical, emotional or spiritual.

Immediately my face, clear through my ears, turned crimson red when talking about sex with a priest! But, recognizing that this was one of the most important and defining characteristics of the community, I knew I could not ignore this vow. Sensing that I was feeling uncomfortable, and himself quite used to answering questions on the subject, Father Lawrence started off in a way only he could answer, "So the chastity is uh well uh watch your boys [testicles]. Ha-ha, but you know at this point in my life I don't even think about that anymore. It is so much more than the physical implications you think about. Maybe when I was younger it was a much more physical understanding, but now, not so much. With a vow such as this you have to be careful of your relationships here, and to be careful of any emotionally intimate relationships."

Painfully aware of the scandals that have come out involving the Roman Catholic Church in recent years, Father Lawrence paused and expounded, "You have to be careful about that with both men and women. It's something you have to work at and continue to do so. You know I think the word is a poor word, and even purity isn't a good word. Moderation is key to understanding it, and there has to be consistency and understanding what one wants. That's the hardest part because you change through the years, and I entered right after high school. You have to learn how to trust others, that's absolutely key-you have to give them the 
respect that they are due. But don't overdo it, you've got to live you know."

Still thinking about the answer given to me by Father Lawrence, I asked Father Conrad the reason for the vow. He squirmed in his chair, internally processing the question, and then answered, "To [us] your relationship with God is your primary relationship. The fact that you have a vow of chastity means that you are freer to be of apostolic service because you don't have to worry about raising your family, or your spouse. It's very common that many of the priests don't think this is the hardest after initially thinking it would be. I hear often that obedience is the hardest, but to me chastity is the hardest."

So, the vow of chastity allows Jesuits to fully immerse the totality of themselves in whatever their ministry is during their career. There is a paradox here, best described by Father Lawrence: "We came and entered for community, and then in that community we learn to be individuals for the purpose of ministry. But then when we go out, we go into communities, you see, so we are building again. Often that community is smaller and that is a challenge because you can't get lost in it. After time, you become some of your own person, and mature and develop with that ministry, and then at this stage of life you come back into the community [of Jesuits] and that's tough.”

This difficulty was evident in the life experience of Father Shawn. While he has loved his life, he did not intend on becoming a Jesuit until after his undergraduate education. In fact, until a few months before his orders, he had a girlfriend. This was and still is the hardest vow for him, but not because of the physical aspect, and especially not now in old age when he doesn't really even think about sex. "Yes, I am human, and I've lived [my] entire life with the same physical urges as any other human," he explained, but it is not difficult to give up the physical with a lot of intentionality in prayer. What is difficult is the sense of not being known, or the connectedness one gets from having an emotionally intimate, exclusively committed relationship with one other person for life." Father Shawn continued, "Over the course of the years, I've had many good friends that are married couples. Over those years I've gone on several vacations or trips with those couples that were my friends. Now, I remember with one couple specifically, we had rooms that were back to back to each other. During that trip what really struck me was when I heard them at the end of the night. I could hear faint whispers of them talking and catching up on the day or any thoughts they might be thinking. I could hear them talk to each other in ways that no other human in this world could. To both of those people, there was no one in the world that could know the other, their partner, in the way they did. And there was no one in the world that they could be known in the ways that they were known by their partner. And in living a chaste life, a life under the vow of chastity, you give that up. And that is what makes this vow so difficult.”

Understanding this vow as predominantly a physical limitation not only cheapens the depth and power of the commitment, but doing so makes light of the longterm ramifications of such a vow for the individual in this sort of community. The vow of chastity looks to reach into the depths of all that it means to be human, and requires a sacrifice that taps into the emotional, spiritual, and physical yearnings of our very being.

\section{Obedience/Obedience to the Pope}

The most self-explanatory of all the vows is the vow of obedience. This vow, in its most literal sense, means listening to your superior's orders and having that shape your ministry. Considering the very literal meaning of obedience, I thought it sensible to ask the superior of this community about its value. Carefully thinking through his words, Father Grant answered, "Commonly this is commented on as the most difficult vow to keep as the years continue. Like you probably understand now, obedience means just that-to be obedient to your superior. You see, this vow is pretty important to the general structure of our order and to our way of life. You have to remember what I said earlier-everything comes back to being immersed in your ministry. And, at the foundation of our Order, we were intentionally set up to be missionally-focused. So, it is important to be able to be sent by your superior, who theoretically understands not only your skills, but also the needs of the ministries of the Order, and after prayer can send you where he feels God is calling you. And, with the vow of obedience, you obey and allow yourself to be sent, or listen to what your superior has for you, and it can be tough to obey when you feel your superior is misusing your skills and gifting."

I then asked him what the implications were for his own role in this community. He answered, "Well, I try to use it sparingly but there are times when I really do need to pull that card here. Sometimes there are residents here who may have some event where they need to go to the hospital. Now, you see, I am trained in gerontology, so I wouldn't send somebody to hospital unless it was really necessary. We have a lot of stubborn people here that refuse to go to the hospital despite the urging of the nurse or one of the medical staff, and sometimes I need to pull that card and tell them as the superior 'I'm telling you that you really need to go."” Thinking of my own experience with my grandfather's stubbornness to listen to his own bodily needs, I laughed, and said I could see how that would be a useful vow. Father Grant agreed with me, but then noted, "It is a little odd as I am the youngest one here and I have 
to tell them what to do. These were great men in their careers, and all have a richness that they bring to this community. It is something I am very wary to use."

I asked about obedience to the Pope. Pausing to think for a minute, he answered, "Obedience to the Pope in the strictest sense is an obedience to being called to missions. It is not really obedience to the Pope himself. When Ignatius was living literally in the same area as the Pope, this vow seemed much more relevant. Especially when the Pope would give Ignatius direct orders to then give to members of the society. It is out of that relationship that the development of that fourth vow came into being. While today's current Pope is a Jesuit, the average member of the order has very little interaction with him, and thus in general one is rarely in a position where he would need to be directly obedient to the Pope." Obedience to the Pope, then, is a largely theoretical extension of obedience to superiors in general.

\section{Concluding Thoughts on the Vows}

There is a certain truth or integrity to the living of the vows that can only be seen in a community like JCE. Conforming to the vows takes place over a lifetime, and it is only at the end of life that its full impact is realized. This was hit home by a simple conversation I had with Father Lawrence as he was walking to lunch. I asked him what had changed in him after all of his years living a life as a Jesuit. He turned and looked, and in a moment of transparency answered, "The vows. In all honesty I have no idea when the actual vows took place. And I don't mean literally when I said them. In fact, when I first said them I really thought I meant them, but I'm not sure I truly knew at that moment what I was saying. I have no idea when these vows took shape in me-I was a kid. As far as I'm concerned I probably didn't know what the hell I was doing, but I knew it was satisfying. It took time for me to understand the meaning of those vows. You see, I came in right after high school, and back then high school was still a place of innocence. So it took time and experience to let these vows take place in me and shape me. It also took the grace of God working through others to help develop this in me." Thus the vows take root in the individual, forming and shaping him into the person he becomes as a Jesuit over time.

\section{The Principles}

The observation of the vows is supported with two principles for living as a Jesuit.

\section{The Virtue of Indifference}

Fundamental to living the life of a Jesuit, especially in this community, is the virtue of indifference. To explain this virtue, I am brought back to Father Shawn. As someone who has changed vocational ministries along with locations multiple times in his life, Father Shawn described this principle in terms one would expect from an authority on Teilhard de Chardin: "All creations can be good. In their basic goodness we can have them-they are for us and God's good creation. Sometimes things are for us but we can't have them. The only thing we must have is God. If it is good for me and good for the ministry in God, I will have it; if it is not you let it go. Essentially, we are to live in a way that will be for the greater glory for God. And it is important to remember all things in this creation are not the end, for God is the end."

Indifference is a loaded word. It can be interpreted negatively, but in this case it is not. Somewhat counterintuitively, it is caring enough to not care about something. When it comes to the vow of obedience, it is caring enough to let go of what you think is the right thing or what you want, and trusting that your superior knows you well enough, knows your needs and sees your skills, and through prayer, sends you to where you need to go. When it comes to chastity, the virtue of indifference recognizes that relationships are good, but that one must let go of those relationships to be fully immersed in the present and operate in ministry completely. When it comes to the vow of poverty, this virtue allows one to recognize that material things are good, and ownership of things can be good, but the ability to let all of those things go is fundamental to conducting ministry for the greater glory of God.

Father Lawrence explained, "The virtue of indifference doesn't mean you don't care. It means by choice you are opening yourself up to a certain situation and in that situation you are opening yourself up to your superior's orders. It doesn't mean you always have to agree, but you must open yourself up to them, sometimes most importantly when you disagree. And then you will work from that point on. The assumption is that when you do that you're willing to listen, respond, and not fight them. But indifference means you care enough to be dependent upon the will of another by your own choice."

The Jesuit vows come at a very high cost. To fully live them out, cultivating a virtue of indifference is necessary as it opens up the individual to the community and to a complete infusion of one's life with one's ministry. It orients the individual to a posture of finding God in all things and to the ultimate point of any ministry in the Catholic Church-leading souls to God. What a Jesuit gains from such a life is an identity as 
shaped and immersed in a community lived in the presence of God.

In every interaction I had with the priests and brothers at JCE, I brought up this virtue. Unanimously, they regarded the virtue of indifference as fundamental to keeping all three vows and living a life of ministry. Yet, it is important to avoid idealizing this life or these vows. When talking to residents, they overwhelmingly made a point to mention that it can be incredibly frightening to live a life such as this one in which your life is not your own but given to something greater. The virtue of indifference is the only way to handle the loss of control implied by such a life and to find the peace that comes from God through Christ. Still, especially through the Ignatian spirituality of contemplative prayer, this is a life that Father Lawrence says can be paradoxically very freeing, despite the cost.

This seeming lack of individual autonomy or agency over critical aspects of life is in conflict with major pillars of our society, such as the narrative of the American dream, concepts of individualization, self-worth through one's own works, and being a self-made governor-the captain of one's own ship, if you will. Yet most of the Jesuits in this community are Americans and were adults before they took their vows. Furthermore, the ministries that they have undertaken are also situated within American culture. American culture values individualization, autonomy and selfgovernance; accumulation of resources and money; and occupation determining identity and value. The Jesuit vows are subversive of the American narrative of individual success, and directly oppose American values. When asking Father Lawrence about the conflicting identities that an American Jesuit must face, he simply replied, "there is a peace that comes because God speaks. If there is peace, God spoke-he doesn't speak to cause turmoil. He will speak in turmoil but his purpose is to bring peace."

Near the end of life, the virtue of indifference is not only relevant but especially necessary. After living years, decades, or an entire lifetime in various ministries of the Society, the individual members of the JCE community have very different histories. All bear the scars and the legacy of a life lived out in one circumstance or another according to the vows. And a Jesuit does not retire-for he is called into a ministry of praying for the Order. But he faces an extreme change from a life once lived full of intense complexity and constant tasks. This can be problematic for the individual. So, it is important then, especially at this stage, to have developed and fully appreciated the virtue of indifference.

\section{Finding God in All Things}

Few statements can capture the overall ethos and goal of the Jesuit order, and the JCE community, like the phrase, Finding God in All Things. It refers back to the original question of what it means to be a Jesuit, and is the principle foundation for all of the vows. Members are instructed to use the things in this world to find God and salvation. But to find God in $A L L$ things is also an attitude. It is a realization and acknowledgment that God is working in everything.

In the design of the community, Ignatius developed exercises to help brothers learn to find God in all things. At the end of a very long conversation, Father Lawrence, a former spiritual director, decided to explain in depth how he found God in all things through these exercises. The older man spoke quietly, resting on his cane, but when he began talking about this, it seemed as if new life had entered his body. Speaking with authority he proclaimed, "There is a principle foundation that serves as a basis: recognizing God's love. You find God's love through prayer. The spiritual exercises are prayer exercises. You can find on the Internet many different descriptions of these prayer exercises. Then comes reflecting on your life and finding the imperfections or brokenness in you, the sin, and recognizing the mercy and love of God. After that we start looking to rebuild our lives, and think about what God has done through Jesus Christ. And the rest of the exercises are spent on the life, death, and resurrection of Christ. And then the final stage in this is embracing God's love-not just recognizing it, but responding to it more fully."

Sitting there in this moment, I found myself on the edge of my seat. It felt as if the man in front of me was instantly transported back into his former vocation and was directing my own spiritual development. He continued. "You see how that pulls it together more fully? You see, you start with recognizing God's love and finish more fully with recognizing and responding to God's love. It is through God's love and mercy that you can respond to God's love and receive it. It is important to realize that your response is a part of that recognition of God's love now at this stage of the spiritual exercises.” Seeing I was mesmerized by his impromptu teaching, in full spiritual director mode, he gave a warning: "It is very important that you do not ever attempt this without direction. Over time this sort of daily prayer can keep you focused. It starts to permeate your life...because you're living what you have been praying about. Then you meet once a week with a mentor-someone who knows how to handle the process. The beauty of this prayer is that it is taken into your daily life without you interfering with your daily life, but you are more conscious of the whole spiritual nature ingrained in your daily life."

Walking away from the room, I realized the importance of discipline in the spiritual exercises. Yet, I still needed to understand how in this community they were able to Find God in All Things. The answer came 
from a concrete instance given to me by Father Donaghy. One day sitting in his room in the middle of a conversation on how he was feeling, he suddenly looked down at his legs and paused. Then, looking back up at me, I can only assume he felt he needed to explain. He stated, "Earlier today I had to go down to Hopkins for a check up on my situation, which could be considered dire because it affects my walking and that sort of thing. I can look at it two ways-either I get very angry, or I say to myself, this is God working somehow through me, and I have to submit to God and allow him to work through me. Rather than be depressed, [I can] realize this is what God wants, so it is an attitude of trust and surrender. So that would be one example of finding God in all things."

Continuing this thought he exclaimed, "That axiom of finding God in all things is particular to the Jesuits, through Ignatian spirituality. To find God in all things, not just in some things, but all things. I find him when I'm sick, when I'm happy, when I'm joyful, when I am sad, when I'm praying, and when I'm angry. Ignatius wanted us to be aware of God's work, and allow us to grow, so that we will respond to God operating in nature, operating in me, operating in you-to see God is everywhere!" Somewhat mistakenly, I likened this to a Buddhist tradition or what could be taken as pantheism. Upon hearing this, Father Donaghy refuted my assertion right away with a ferocity I did not think was possible in his current physical state, asserting, "This is not a pantheism! This is finding the Christian God, this is finding the God, the author of creation, in all things. In doing this we can find God, and in doing such continue on the journey to find salvation."

Intrigued by his answer, I asked Father Donaghy what that salvation was. He sat for a bit, and then opened his mouth to speak, but before a response could rush out, he immediately shut it again, deciding to choose his words more carefully. Realizing the raw authenticity of this moment, I sat there in total silence, refusing to be the first to break the stalemate. Finally he pulled a book from the shelf and started leafing through the pages and started to speak, "Salvation is finding our completion and our fullness of life in Jesus. My conception of eternity is living in Jesus' presence forever. And that presence of Jesus will be very fulfilling and life giving. And this is really what holiness is. I think one way in which I find this every day is in the mass. Because in the Mass we recapitulate what Jesus did in the Last Supper. In the Catechism it says, 'salvation comes from God alone, and because we receive the life of faith through the Church, she is our mother.' Salvation would be reaching the beatific vision. The beatific vision is the true fulfillment of all of man's longings. What we are really created for is to reach the beatific vision. That's what we will be doing for all eternity. Of course the whole concept of eternity is mind-boggling. I mean everything we have known has had an end...Oh here, listen to this," he opened the catechism to explain the beatific vision, "It is the desire for true happiness that frees man from his immoderate attachment to the goods of this world so that he can find his fulfillment in the vision and beatitude of God."”

Finding God in all things, then, is a vital undergirding for Jesuit identity and a way to find continued purpose in each moment. And it produces a sense of joy that runs deep. This is no superficial mantra that might be found in a self-help book. Rather, it is an intentional way of engaging and processing all that the members encounter in their lives. It is a choice, a choice that is made multiple times a day, every day, throughout their entire life as Jesuits. Ultimately it allows them to find purpose in the mundane, and gives them hope in the final failings of their body, humanity, and the world.

\section{Jesuit Identity}

Clifford Geertz suggests that the purpose of ethnography is "not to answer our deepest questions, but to make available to us answers that others...have given and thus to include them in the consultable record of what man has said" (Geertz 1973:30). True ethnographic fieldwork is done through data collection and theorizing by way of "thick description." Still, to make sense of the data I have obtained here, we must now revisit the question of identity and purpose for members of the JCE.

Every individual, as a product of complex social mapping, carries multiple identities, each vying for top ranking in the prominence hierarchy of identities (i.e. occupation, family role, and cultural identity, etc.). It is evident that for all members of this community, the ideal self and the primary identity is that of being a Jesuit. Consequentially it is Jesuit identity that has given the members of JCE a sense of meaning and purpose that persists to this stage of the lifecycle.

To restate: the human 'self' emerges out of social interaction predominantly fueled by the perception, reflection, and response to the perceived meaning of social events. Thus, in order to develop a 'self' the human creature must be situated within some form of a social grouping, and have a role or roles within that context. In performing the duty of these roles, an identity is formed in association with the roles. For the members of the Jesuit Order, the largest social entity that provides them with an identity is the order itself, a worldwide institution that spans countless borders, cultures and even generations.

Yet, every resident grew up with a past that included family assigned roles, ethnic/cultural ties, socioeconomic status, geographic identity, etc. Each of these pasts was formative and influential on the individual 
before they entered the Jesuit Order. In fact, the Jesuit Order by design encourages a limited keeping of these roles. ${ }^{6}$ That said, every one of the members of this community willingly chose to enter this order and take on a new identity-to live life as a Jesuit. This choice is usually made at the earliest stages of adulthood, such as after high school or university, a time when individuals are still impressionable and have most of their life left to live, but when they are also already formed by American values. Thus, the measurements of success that form American identity must be subverted and subordinated to Jesuit identity.

Nowhere is that more clear than in the performance of an occupation. The identity of one's former occupation is perhaps the second strongest identity in this community, and can be quite a source of struggle for the members. The struggle is best seen in those who have gone from a long and distinguished career in their field to sudden retirement. For them, their identity as a Jesuit is tested maximally due to the drastic shift from living a full professional life to a relatively disconnected life where they now reside. Practically every member I met in JCE was dealing with the struggle of lost professional identity, leaving them all the more dependent upon their identity as Jesuits.

In fact, the happiest members of this community, and those who seem to be the healthiest both physically and emotionally, have a connection to their past ministries in some way, shape, or form. For instance, the way Father Lawrence has been able to make peace with his circumstance is to not allow himself to drop out of people's lives. Part of his weekly routine is to pray for and write letters to friends from his former ministry. Making peace with this change is crucial to all at this community, and retaining some connection to former professions is a common way to do it. Attempts to keep the connection alive range from letters, to trips out to previous foundations, and to simply walking in nature reminiscent of where they found God in their old ministry.

Looming large is a circumstance that is heavily stigmatized by American culture, the incapacities of old age. Each resident at JCE needs some form of late-lifecare from trained professionals on a regular basis. Yet, the very design of the Jesuit lifestyle allows for a continued sense of identity, meaning, and purpose to occur at this potentially difficult stage. The entire community is built around a web of individuals supporting each other in performances such as the mass, individual daily prayer, and semi-annual retreats to perform the spiritual exercises. In fulfilling these performances the individual is able to maintain the ideal 'self' seen in Christ, and to participate in meaningful community as a part of the Society of Jesus.
The benefits of active maintenance of an ideal self, or a unique identity, can be significant. Dr. Yeates Conwell (MD), who has done extensive research on the subject, writes in the American Journal of Preventative Medicine, "suicide in later life is a major public health concern in the U.S., where more than 6,000 older adults take their own lives every year. Suicide prevention in this age group is made challenging by the high lethality of older adults' suicidal behavior; few survive their first attempt to harm themselves," and often these occur in assisted living communities (Cornwell 2014:244). When Jesuits are unable to continue the role performances of their prior occupations, they simply shift their responsibilities to another form of ministry, and when their bodies begin to fail them, they have the practiced support of the community to remind them of their primary identity.

This is in robust contrast to other assisted living communities in America. The physical body that has been the vessel of life begins to fail. Often with this diminishing there is a lack of mental, physical, and social activity that results in a loss of identity, purpose, and meaning. But at JCE, Jesuits are still responsible for finding God in all things, and are able to live according to their chosen identity. Practically speaking, it is through the structuring of daily life that identity and meaning are sustained. Father Donaghy says, "the whole function and the basis of my life in this community is trying to find a prayerful union with God through the Eucharist. The Eucharist is really the bedrock of everything....an increased awareness of the power and the importance of the Eucharist in life, in life now and in the future."

The elderly are a marginalized demographic in our society. Heightened rates of depression and suicide in this group point to a loss of purpose and identity. With the deterioration of the body and admittance into low level assisted living communities, the elderly lose our society's preeminent identity based on occupation. Also, they are removed from the daily manifestation of their most meaningful relationships. Contrary to this situation, which is taken for normal in American society, it is evident that members of the JCE are thriving during this late stage of the lifecycle in ways that set them apart from other late life assisted living communities. To be a Jesuit is an identity that takes a lifetime to develop. It is an identity that disallows the usual standing in our society, and instead develops an altogether different framing of the individual as a member of a larger order and with a larger purpose. Thus, that identity allows each member of the community to maintain the deep and meaningful relationships that are key to a sense of purpose in the latter stages of the life cycle.

\footnotetext{
${ }^{6}$ The Jesuit Order was one of the first religious orders to allow members to keep the name of their families.
} 


\section{Concluding Theological Reflections}

In previous sections of this article, I have endeavored to establish that as humans we are inherently meaning-laden creatures with identities that are formed in social contexts. Now I would like to make the case that as humans we not only develop our 'selves' through communication with others as seen in symbolic interaction and identity theory, but also as seen in Christian theology. In the line of Alastair McFadyen, James Smith, and Thomas Merton, it is my contention that as created beings we discover our humanity through our relations with others, and in doing so become image bearers of the Triune God. The theology of the Trinity presents God as fundamentally relational in nature. Suggesting that this relationality is also in us means that the human individual cannot fulfill that image alone. The individual must live and engage in authentic community and relationship with others to fully realize that mandate. Furthermore, in interaction with others, the individual not only reflects the image of the Triune God, but also produces the 'self' and begins the journey of constructing personal identity. Thus, in the case described here, Jesuit identity not only reflects God's nature, but also discovers a way to become more fully human-in other words, develops human flourishing (cf. Flett 2011).

McFadyen describes the Trinity as, "a unique community of persons in which Person and relation are interdependent moments in a process of mutuality. Each Person is a social unity with specific characteristics unique to him or her but whose uniqueness is not an asocial principle of being. The terms of personal identity within the Trinity identify not just as unique individuals but the form of relation particular to them" (1990:27). Essentially, these three Persons can only be who they are through their relations with one another, yet have a divine nature in common. Recognizing this relational characteristic of the Triune God as the model for the human creature, we are able to see its importance to the construction of our 'selves' and to the fulfilling of our mandate as image bearers on the journey toward salvation.

Christian theology states that one of the Persons of God, while fully divine, became fully human, and in that embodied state made the restitution of right relationship between God and ourselves possible. It is as a response to this invitation on God's part that restitution of relationship is made, and in Jesuit thought, that response involves holy practices and habits that are what James Smith calls a "governing orientation" to the world (Smith 2009:80). Habits shape our desires, reminds Smith, and thus help construct our telos, or purpose (83). Recognizing the formative power of habits, and understanding that as humans we are first and foremost social creatures, we can see that only in community, with intentional practice, can we come to a place of finding our identity in imaging God.

In the JCE, being a Jesuit is framed as living a life that mirrors Christ in the context of a community that engages in common practices, such as participating in the Mass and receiving the Eucharist, and a constant evaluation of one's motivation in all that one does. The vows of poverty, chastity, and obedience are habits which allow the individual to develop the disposition of finding God in all things, ultimately ending in salvation. With the intentional practice and construction of these foundational habits in the context of community, the individual resident of the JCE, no matter their state of physical deterioration at this late stage in the life cycle, is able to maintain their identity as a Jesuit, continue relational practice through ministry, and build upon a profound sense of meaning in life.

For the members of JCE, however, there is an even greater goal: It is leading souls to God, that is, to salvation. Thomas Merton describes salvation in relational terms: "By salvation I mean first of all the full discovery of who [the individual] himself really is. Then I mean something of the fulfillment of his own Godgiven powers, in the love of others and of God. I mean also the discovery that he cannot find himself in himself alone, but that he must find himself in and through others" (Merton [1955] 2015:XV). For Merton, then, salvation involves discovering the true self, not only as "a subjective, psychological thing, a self-realization in the order of nature. It is an objective and mystical reality-the finding of ourselves in Christ, in the Spirit, or, if you prefer, in the supernatural order" (XVI).

The human person emerges from a fundamentally relational process situated within a distinct socialframework. It is this decidedly communal construction that parallels the emergence of the Triune God in Christian theology. For the members of JCE, identity is formed by more than simply developing the 'self' by relational means. It involves the emergence of a particular 'self', firmly situated within a distinct community, tethered by a common ontological framework and by a set of orienting principals, habits, and practices in relation to God, the other, and the cosmos. Even in the latest stage of the life-cycle we can see the members of JCE have this identity and continue to live within this community, thereby maintaining this 'self'. For this is a community with the explicit goal of finding the completion and fullness of life in relation to Jesus. To achieve this goal, the Order requires its members to live in radical community, bound by the vows of poverty, chastity, and obedience, all-the-while cultivating the virtue of indifference to find God in all things. For this is what it means to be a Jesuit. 


\section{Bibliography}

Berger, Peter L., and Thomas Luckmann. 1967. The social construction of reality: a treatise in the sociology of knowledge. New York: Anchor Books.

Blumer, Herbert. 1969. Symbolic interactionism: perspective and method. Berkeley: University of California Press.

Bohannan, Paul, and Dirk Van Der Elst. 1998. Asking and listening: ethnography as personal adaptation. Prospect Heights, IL: Waveland Press.

Burke, Peter J., and Jan E. Stets. 2009. Identity theory. Oxford: Oxford University Press.

Conwell, Yeates. 2014. Suicide later in life. American Journal of Preventive Medicine 47(3):244-50.

Fleming, David. 2008. What is Ignatian spirituality? Chicago, IL: Loyola Press.

Flett, Eric. 2011. Persons, powers, and pluralities: toward a Trinitarian theology of culture. Eugene, OR: Wipf and Stock.

Geertz, Clifford. 1973. The interpretation of cultures: selected essays. New York: Basic Books.

Ignatius, St. and J. F. X. O'Conor. 1900. The autobiography of St. Ignatius. New York: Benziger Bros.

McCall, George J. 1970. Identities and Interactions. New York: Free Press.

McCall, George J., and J. L. Simmons. 1978. Identities and interactions: An examination of human associations in everyday life. New York: Macmillan.

McFadyen, Alistair I. 1990. The call to personhood: a Christian theory of the individual in social relationships. Cambridge: Cambridge University Press.

Mead, George Herbert, and Merritt H. Moore. 1936. Movements of thought in the nineteenth century. Chicago, IL: University of Chicago Press.

Mead, George Herbert, Charles W. Morris, Daniel R. Huebner, and Hans Joas. 1934. Mind, self, and society: the definitive edition. Chicago: University of Chicago Press.

Merton, Thomas. 1955. No man is an island. New York: Harcourt, Brace.

O'Malley, John W. 2014. The Jesuits: a history from Ignatius to the present. Lanham, MD: Rowman \& Littlefield Publishers.

O'Malley, John W. 1993. The first Jesuits. Cambridge, MA: Harvard University Press.

Polanyi, Michael. 1966. The Tacit Dimension. Chicago, IL: The University of Chicago Press.

Smith, Christian. 2010. What is a person?: rethinking humanity, social life, and the moral good from the person up. Chicago, IL: The University of Chicago Press.

Smith, James K. A. 2009. Desiring the kingdom: worship, worldview, and cultural formation. Grand Rapids, MI: Baker Publishing Group.

Teilhard de Chardin, Pierre. 1960. The divine milieu. London: William Collins Sons \& Co. Ltd.

- 1965. Hymn of the Universe. New York: Harper \& Row.

2008. The phenomenon of man. New York: Harper Perennial Modern Thought.
Traub, George W. 2008. An Ignatian spirituality reader: contemporary writings on St. Ignatius of Loyola, the spiritual exercises, discernment and more. Chicago, IL: Loyola Press.

Turner, Victor. 1967. The forest of symbols: aspects of Ndembu ritual. Ithaca, NY: Cornell University Press. 